\title{
三重県に拈ける粥占い神事
}

\author{
水谷令子・久保さつき・西村亜希子 \\ (鉿鹿短期大学)
}

\section{The Year's Fortune-tellings with the rice in Mie Prefecture}

Reiko Mizutani, Satsuki Kubo and Akiko Nishimura

Suzuka Junior College, 1250 Shono-cho, Suzuka-shi, Mie, 513

\section{$\overline{\mathbf{T}} 513$ 三重県鈴鹿市庄野町 1250}

The year's fortune-tellings with rice in Mie prefecture are investigated and the relation between them and rice cultivatian is researched in this paper.

1. The range of the year's fortune-tellings with rice extends from Yokkaichi to Matsusaka and this region doubles a rice-producing district in the Ise Plains.

2. The objects of this divination are almost early-, middle-, and late-ripening varieties of rice plants. In a few cases, wheat, adzuki beans and vegetables are also added to them.

3. The divination has been taken shape as folklore festivals on Ko-Shogatsu, the new year's day according to the agricultural calendar, and afterwards, it also has become a Shinto rite such as praying for a fruitful year.

4. In some areas, they divine with adzuki beans and rice gruel. We suggest that this has a relation to the custom of eating adzuki beans and rice gruel, and 'zenzai', sweet adzuki soup with pieces of rice cake, and to pray health and happiness in the new year on Ko-Shogatsu.

三重県に扣ける粥占いを調査し, 稲作農業との関連について考察した。

1. 粥占いは，四日市から松阪までに分布しており，この領域は，伊勢平野の稲作地帯とほぼ一 致している.

2. 占いの対象は, ほとんどが, 稲作の早稲, 中稲, 晚稲である. 一部では, 麦, 小豆, 野菜類 が加わっている.

3. 粥占いは抢そらく，小正月に民俗行事として行われていたものが，後になって，五穀豊穣を 願う神事としても行われるようになったと考兄られる.

4. ある地域では，小豆䋆を用いて占いが行われている．小正月に小豆䋆やぜんざいを食べて無 病息災を願ら風習があることとの関連が考兄られる。 


\section{1. はじめに}

天候や農作物のでき具合を含めた 1 年の吉凶を占ら年 占いは古くから行われていたといわれる。三重県に执い ては, 桑名郡の多度大社 ( 5 月 $4 \cdot 5$ 日), 猪名部神社

（4月 4 ・5 日）の馬を使った「上げ馬神事」や志摩や 南紀地方には年の始めに弓引きによって占いをする神事 も残っている.

米や小豆を使った年占いは，日本各地にみられる．日 本のまつり・年中行事事典1)によれば, 諏訪大社（長野 県下諏訪町), 金鑽神社 (埼玉県児玉郡神川村), 三峰神 社 (埼玉県秩父郡大滝村), 貫前神社（群馬県富岡市）, 大物忌神社 (山形県飽海郡), 佐太神社 (島根県八束郡 鹿島町）などで竹筒を用いた占いが実施されている．大 物忌神社が 1 月 5 日，佐太神社が 2 月 15 日以外は 1 月 15 日に実施されている．諏訪大社の筒粥神事では，42種類 の作物の出来を占い, 判定結果を大声で参詣者に知らせ るといら。これらは農耕, 特に稲作農業と関連が深いと いわれ，現在でも三重県内に揖いては鈴鹿市と松阪市に よく保存されている.

日本の神社で行われる神事のほとんどは稲作との関連 が深く, 予祝儀礼, 播種儀礼, 田植儀礼, 成熟儀礼, 収 穫儀礼と相次いで行われてきた。粥占いは, 御鈢神事と 同時に行われた予祝儀礼であったと考兄られているが， 筆者らの調査では, 米作りの所作をまねる儀礼である御 銋神事と粥占いを同時に実施している例は見られず，御 鏉神事は粥占いより時期の遅い春の例祭にとり込まれた と思われる. 伊奈富神社では 4 月16日に, 少許鲁神社で は 3 月 7 日に, 所作を伴らことはないものの春例祭の別 名として御銋神事の名称が残っている.

粥占いの意義は, 天候によって大きく左右される稲作 作業に先立って, 天気予報などない時代に, 占いによっ
て作柄や天候 (雨量) を予測し, 作付け計画の参考にす るものであるが, 現在は実質的な効用はないものの, 神 事の一部, あるいは地域の民俗行事として伝承されてい る.

继占いの方法は 3 種類ある2). 1 つは凹型といわれる もので竹の管筒を粥の中に入れて，粥が煮えた後に筒を 取り出し，筒に詰まっている粥の分量や性状の比較によ ってその年の穀物の作柄などを占らものである。この型 は社寺で行われる場合が多いが，民間で行われた例もあ る. 三重県に残っている粥占いはすべて凹型であった。

2 番目は凸型である. 凸型の粥占いは, ヌルデ（白膠木： らるし）の枝を使い，その半分の皮を削って白い木肌を 出して作った粥掻き棒を粥の中に入れ, その棒に付着し た粥の量によって作柄を占らといらもので，山梨県では 極めて盛んに行われていた．粥掻き棒の形式は多様であ るが，その祖型は木肌を白く削りだした箸であったとい われる. 多量の米粒が付着した粥掻き棒は豊かな稲穂の 象徴でもあると言われている2). 3 番目は粥の湿乾扣よ び䉼の扱いなどに関するものである. 粥が固いと田が割 れる兆しがあるので凶，やわらかいと吉とするものであ る. また，炊きあがった粥を器に入れて床の間に置き， 翌朝固まり具合を見て，その年の運を占らものである. これらは水田の湿潤を求めることで「水 (雨量) の予祝」 となっている. 本稿は三重県に保存されている粥占いを 調査して, 代表的なものについて紹介し, 稲作行事との 関連を考察すると共に, 三重県外の例とも比較した.

\section{2. 調査方法之時期}

1993年に三重県神社庁を通じて，三重県下の全神社 815 社の宮司を対象に「食によつわる神事」の実施状況 をアンケート調査した.

しかし，アンケートの回収率 $(29.6 \%)$ は悪くまた

表 1 三重県における粥占いの状況

\begin{tabular}{|c|c|c|c|c|c|}
\hline 神社名 & 地 & 実施日時 & 神事の名称 & 占5対象 & 炊きあがり \\
\hline $\begin{array}{l}\text { 岸田神社 } \\
\text { 小許曾神社 } \\
\text { 阿射加神社 } \\
\text { 敏太神社 } \\
\text { 菅原神社 } \\
\text { 伊奈富神社 } \\
\text { 酒井神社 } \\
\text { 椿大神社 } \\
\quad *\end{array}$ & $\begin{array}{l}\text { 鈴鹿市岸田町 } \\
\text { 四日市市小古曽町 } \\
\text { 松阪市小阿坂町 } \\
\text { 松阪市美濃田町 } \\
\text { 鈴鹿市国分寺 } \\
\text { 鈴鹿市稲生町 } \\
\text { 鈴鹿市郡山町 } \\
\text { 鈴鹿市山本町 } \\
\text { 河芸町北黒田 }\end{array}$ & $\begin{array}{l}1 \text { 月 } 2 \text { 日 } 10 \text { 時 } \\
1 \text { 月 } 14 \text { 日 } 18 \text { 時 } \\
1 \text { 月 } 14 \text { 日 } 18 \text { 時 } \\
2 \text { 月 } 5 \text { 日 } 10 \text { 時 } \\
2 \text { 月 } 14 \text { 日 } 12 \text { 時 } \\
2 \text { 月 } 14 \text { 日 } 20 \text { 時 } \\
2 \text { 月 } 14 \text { 日 } 13 \text { 時 } \\
2 \text { 月 } 21 \text { 日 } 6 \text { 時 } \\
2 \text { 月 } 13 \text { 日夕刻 }\end{array}$ & $\begin{array}{l}\text { 粥占 } \\
\text { 粥試し神事 } \\
\text { 粥試·火試 } \\
\text { 粥試 } \\
\text { 䉼占・火試 } \\
\text { 世例祭 } \\
\text { よだめし祭 } \\
\text { 粥占神事 } \\
\text { 䉼占い }\end{array}$ & $\begin{array}{l}\text { 稲作 } \\
\text { 稲作 } \cdot \text { 小豆 } \\
\text { 稲作 } \cdot \text { 雨量 } \\
\text { 稲作 } \\
\text { 稲作 } \cdot \text { 野菜 } \cdot \text { 雨量 } \\
\text { 稲作 } \cdot \text { 雨量 } \\
\text { 稲作 } \cdot \text { 麦作 } \cdot \text { 畑作 } \\
\text { 稲作 } \cdot \text { 穀類 } \cdot \text { 野菜 } \\
\text { 稲作 }\end{array}$ & $\begin{array}{l}\text { 白飯 } \\
\text { 小豆粥 } \\
\text { 小豆粥 } \\
\text { 白粥 } \\
\text { 白粥 } \\
\text { 白飯 } \\
\text { 小豆粥 } \\
\text { 小豆飯 } \\
\text { 白粥 }\end{array}$ \\
\hline
\end{tabular}

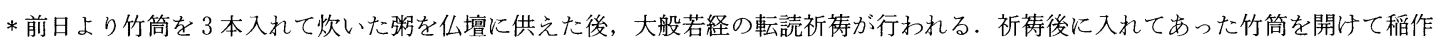
の豊凶を占う。 
記載内容も不十分なものが多かったので，これだけで実 態を把握することは困難であった。

次に1993年から1995年にかけて新聞記事などからの情 報収集, 電話による聞き取りなどで粥占いの実施地域を 特定した.

実地調査は1995年 2 月と1996年 $1 \sim 2$ 月に行った。本 文の記述は大部分観察と聞き取りによるものであるが， 過去の状況などについては一部分, 文献を参考にした. 三重県下の粥占いの状況について表 1 に示した。

\section{3. 結果および考察}

\section{(1) 伊萘冨神社の「势例繁」の検討}

鈴鹿市稲生町の伊奈冨神社の「世例祭」は民俗誌など にも紹介されている神事で，2月14日の夜行われる3).

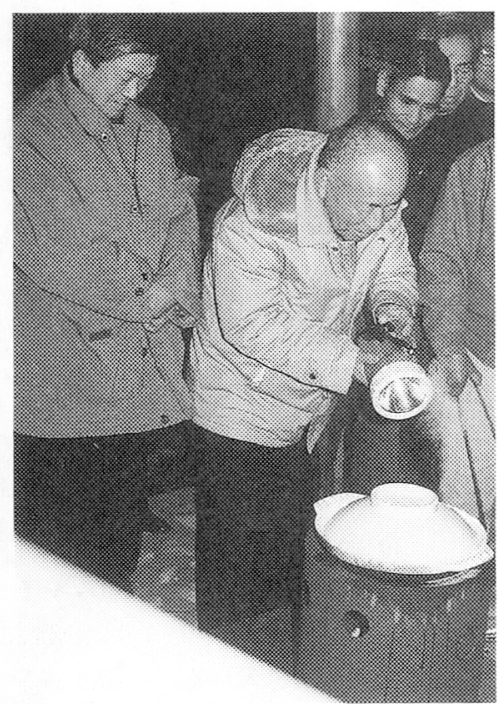

当日夕刻より 宮総代と宮当番 が社務所に集ま り, 午後 8 時に なると移動式の 鼌を拝殿と本殿 の間の通路に置 き,照明のない, 暗闇の中で粥 (炊きあがった 状態はやわらか なご飯）を炊く (写真 1$)$. 一 般には公開され て打らず，特に 本殿に近いとい 写真 1 粥は暗闇の中で炊く（伊奈冨神社 らことで女性の

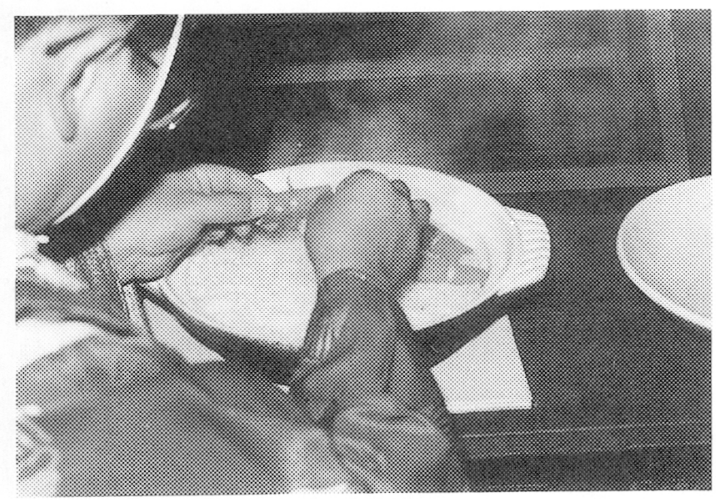

写真 2 宮司が竹筒をあける（伊奈冨神社）
参加は禁止されている．洗米と占い用の竹筒 3 本を白い 土鍋飞入れ，薪を使って粥を炊く。この竹筒は筋目の印 をつけた長さ約 $10 \mathrm{~cm}$, 内径 $2 \mathrm{~cm}$ の二つ割の竹筒を麻系 で結わえたもので毎年同じものを使っている．粥が炊き あがると宮司はじめ宮総代たちは拝殿に移り，粥の入っ た土鍋を神前に供えて神事を行う．神事の後，宮司は麻 糸を解いて筒を開け，中の粥の入り具合を見てそのまま かわらけに並べる（写真 2 )。翌朝竹筒は三宝にのせら れて拝殿前に示され，氏子はこれを見て結果を自ら判断 する，竹筒に入っている米粒が多ければ豊作，少なけれ ば不作とする，炊いたご飯が固いとその年は雨が少なく 干ばつを受ける印とされる。ご飯は小分けして拝殿前に 置かれ，翌朝占いの結果を見に来た参詣者はそれを持ち 帰り，その年の無病息災を願って食べるのである.

昭和初期には，占ら作物が雑穀（その内容は麦・キビ ・アワ), 大豆, 稲の 3 種類であったよらだが4), 現在は 稲のみとなり早稲・中稲・晚稲の 3 種について占っている.

(2) 管䖒神社の「籍苫・炎試」の検討

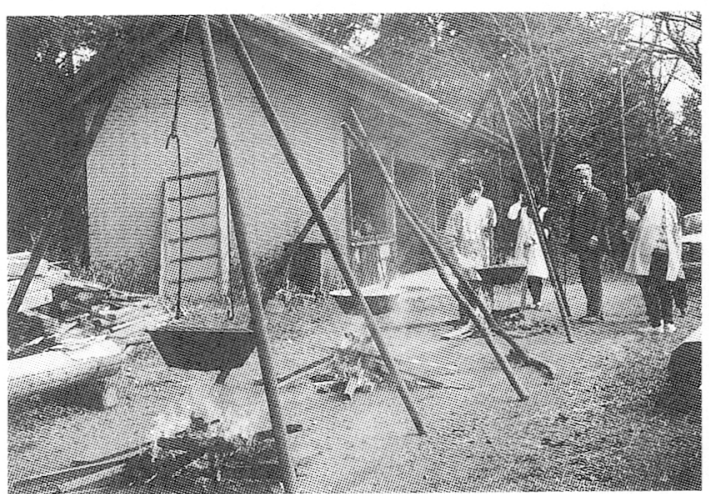

写真 3 境内で倨を炊く様子（菅原神社）

鈴鹿市国府の菅原神社では，2月14日，「粥占・火試」 が行われる.正午すぎ神社の広場に大やぐらを 3 つ組み, 8 升鍋 3 つで粥を炊く（写真 3 ). 粥を炊くのは宮当番 の役目である. その中の 1 つに，占いの竹筒12本を紐で 編んで入れておく，同時に火の中には雨量占いを目的と する「火試」用のカシの小枝12本を銅線で編んだものを 瓦にのせて入れておく，小枝の燃光具合で， 2 月から翌 年 1 月までの雨量を占らのである。「粥占」用の竹筒は 二つ割にしてあり, 長さ $12 \mathrm{~cm}$, 内径 $1.5 \mathrm{~cm}$, カシの小枝 は長さ $15 \mathrm{~cm}$, 太さ $1.2 \mathrm{~cm}$ である. 約 1 時間で粥は炊きあ がり, 竹筒を取り出し, 宮総代が紐をほどいて竹筒の中 の粥の入り具合で大吉・吉・小吉などと判定し，それを 宮司が記録する (写真 4 )。しかし，宮司による神事は 


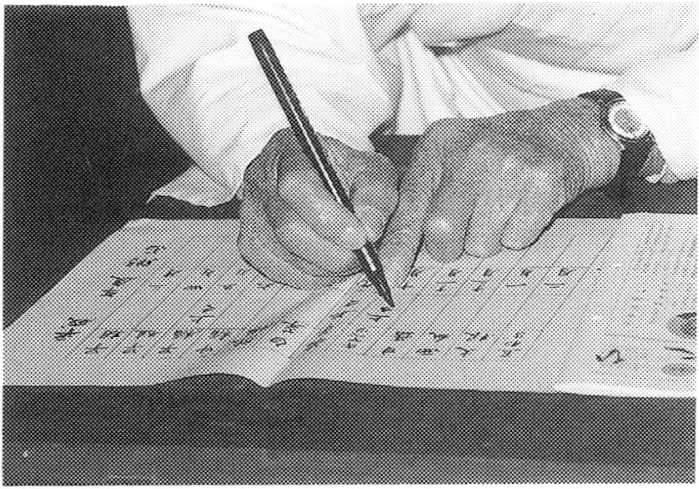

写真 4 「粥占」の結果を宮司が記録し公表する（菅原神社）

粥を煮ている間に行われ, 神事が終了した後, 占い行事 は宮総代たちによって実施され，宮司は単なる記録係で あった．現在では占う作物は12本の竹筒の先頭（編み始 め) から順に早期 (稲), 早植 (稲), 早稲, 中稲, 晚稲, 白菜, 茄子, キャベッ, 甘藷, 西瓜, 大根, 玉葱とされ る、栽培する稲の品種が多様になるに従って占ら対象が 次第に変化してきた様子が推察される.

氏子は，各自で持ってきた椀に䂾を入れてその場で食 ベたり，鍋や弁当箱に入れて持ち帰り，家族と共に食べ て無病息災を願らという。

占いの結果は氏子の間に回覧して作付计計画の参考に されていたといらが，現在は回覽はされても参考にする ことはほとんどないだろらといらことであった。

\section{(3) 阿射加神社の「濑試・然試」の検討}

松阪市小阿坂町の阿射加神社の「粥試 - 火試」は, 1 月 14 日午後 6 時から行われる.この神事は三重県の指定 民俗行事になっており，例年新聞紙上にその様子が紹介 される由緒ある民俗行事である5）6).

神事は特別に作られた室内(調舎) の炉の回りで，大

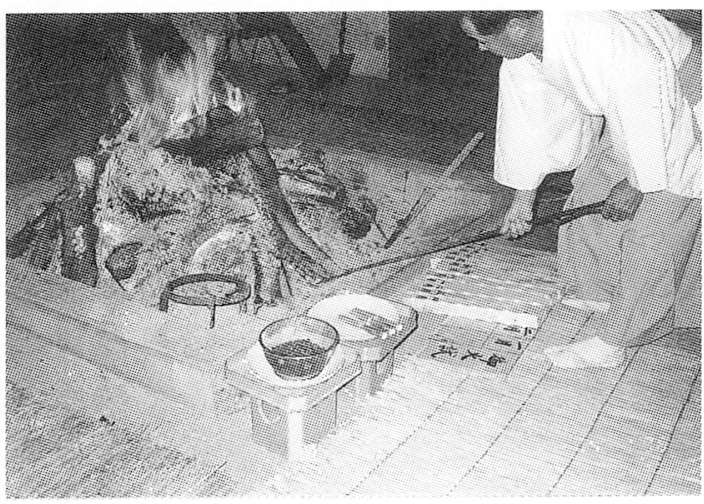

写真 5 「弹試」「火試」が実施される炉（阿射加神社）
勢の見物者の見守る中で実施され，「粥試」と同時に雨 量を占ら「火試」も行われる（写真 5 ).

「火試」は，1月から12月までを墨書してあるカシの 棒を炬の中で然やし，途中で，やはり1月から12月まで が書かれている杉板の上にカシの棒の焼けた部分(オキ) を置き，杉板の然穴具合によってそれぞれの月の雨量を 占 (写真 6 ).「火試」用のカシの棒は縦横各 $4 \mathrm{~cm}$, 長 さ $60 \mathrm{~cm}$ の角材である.

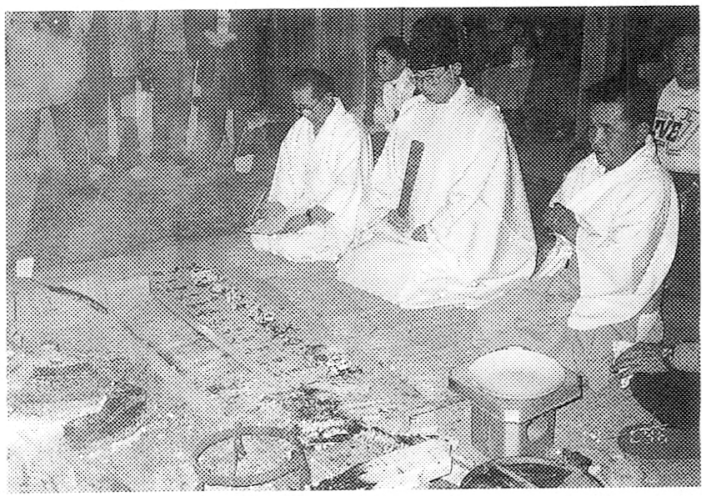

写真 6 「火試」の様子（阿射加神社）

阿射加神社で炊く粥は小豆粥で, 伝承に従って米 5 合, 小豆 2 合を用いる. 三重県に拈いて，小豆を加えるのは 9 例中 4 例であるが，全国的にみると小豆を加光る場合 の方が多い，小豆の粥は，赤い色を食べて冬の陰気を陽 徳で消せるといら意味, あるいはこれを食べれば疫病に かからないといら中国の俗信からきたものといわれる7) が，野本 ${ }^{2)}$ は小豆を稲作にとって不可欠な日の恵みを予 祝する食物と意味つけてる.鍋を炉の中の五徳にかけ, 粥を炊く途中で占い用の竹筒 3 本を入れる. 竹筒はあら かじめ二つ割にしてあり, 長さ $20 \mathrm{~cm}$, 内径 $2 \mathrm{~cm}$ ののを 麻糸で結わ兄て用いる，炊きあがると竹筒を開けて中に 入った米粒と小豆粒の量で早稲・中稲・晚稲の作柄を占 い, 記録する.占いが終わると，オオッーと「トキの声」 を 3 回上げ，皆で万歳をして神事は終了となる. 小豆张 は参詣者に配られる．この神事と同時進行の形で「かん こ踊り」と「どんど焼き」も社殿の外で行われる.

\section{(4) 小許曽神社の「粥試し神事」の検討}

四日市市小古曽町の小許曽神社では, 小正月の 1 月 15 日を中心に一連の正月行事が行われ，「粥試し神事」は その一つである.

小許曽神社は, 明治40（1907）年合祀されるまでは, 東の宮（神明社）と西の宮（小許曽神社）があり，かつ ては, 両宮で同様の神事が実施されていたものが, 統合さ 


\section{日本食生活学会誌}

れた現在では小許曽神社中心の神事となったといら338).

「粥試し神事」は，1月14日の午後 6 時から実施され る. 当日午後から，占いに使う竹筒を莕で編んだり粥を 食べる竹箸の準備などをする（写真 7 ）。宮当番は 14 日 午後から神社境内の清掃, 一連の神事の準備なども行ら. 拝殿の右手前に建てられた籠もり堂には真ん中に炉が作 ってあり，そこに鍋をつるして小豆粥を炊く.8 升鍋に， 米 5 合, 小豆 1 合, 水 4 升といら記録通りに準備して,

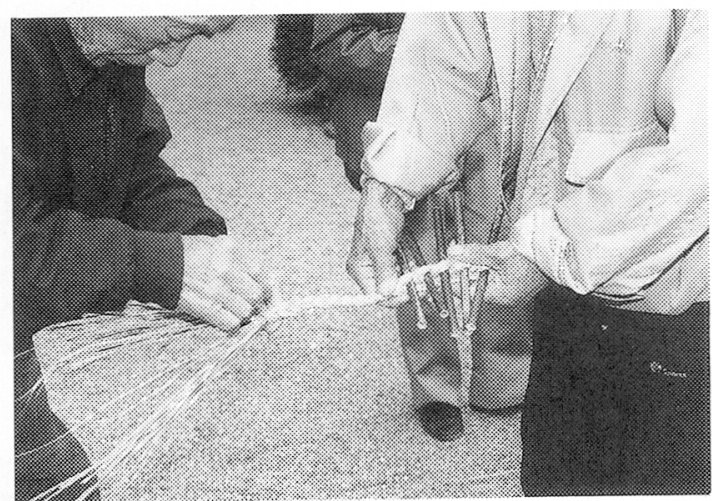

写真 7 「䋆試神事」に使う竹筒の準備（小許曽神社）

宮当番と宮総代が約 1 時間かけて粥を炊く．その際，5 本の細竹を葍ですだれ状に編み，それを炊さはじめから 鍋に入れ粥を炊く．この占い用の竹筒の内径は莕ニゴ 3 本通る程度（約 $0.5 \mathrm{~cm}$ ） と細く, 長さは 3 寸 5 分（約 10 $\mathrm{cm})$ である. 粥が炊きあがると, 粥の中に入れた竹筒を 取り出し, 大きなかわらけに入れ, 三宝にのせて神前に 供光,「游試し神事」を拝殿で行ら。

神事が終了すると, 長老の宮総代がナイフで竹筒を 2 つに割り，占いは中に入った米粒を数觉，米粒の数をそ のまま占いの結果として宮総代が記録する（写真 8 ). 占万対象は，早期 - 早生 - 中生 ·晚生の各稲と小豆の 5

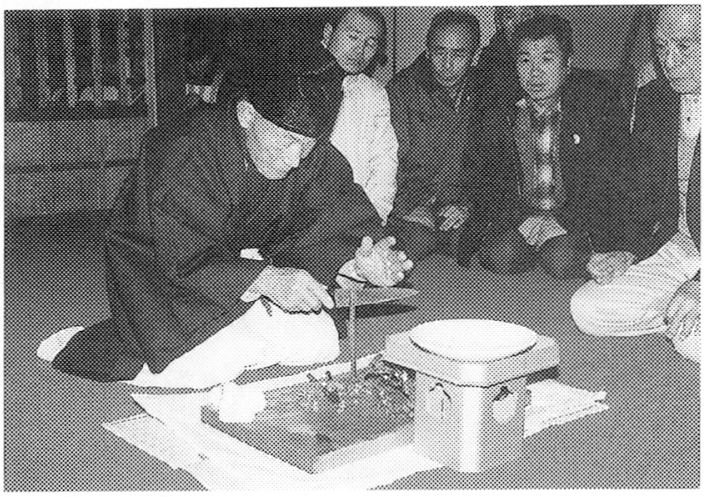

写真 8 長老の宮総代が竹筒を割る（小許曾神社）
種で, 結果は, 拝殿前と社務所に貼り出して公表する.

“早期”の占いは1965年（昭和40年）から加觉られた もので, 作付け品種の変化に対応して占ら対象が増えた と考光られるが，現在においてこの周辺の稲作では早期 と早生以外の品種を栽培することもなく, この占いの実 効性も失われていることとて，ここでの粥占いの変貌は 興味深い.

「粥試し神事」は，かつては旧暦 1 月15日の午前 0 時 から行われたが，明治時代になり太陽暦に変更されたの を期に 1 か月遅い 2 月15日に行らようになった。 そして 太平洋戦争後, 再び 1 月に戻し, 深夜に実施されていた のを，時間を早めて 1 月14日の夕刻から始めるよ5にな った。「粥試し神事」が終了すると小豆粥は参詣者に配 られ，青竹の1本箸を使って食べる（写真 9 ）。これを 食べると 1 年間無病息災といわれ，かなり多くの氏子が 集まる。

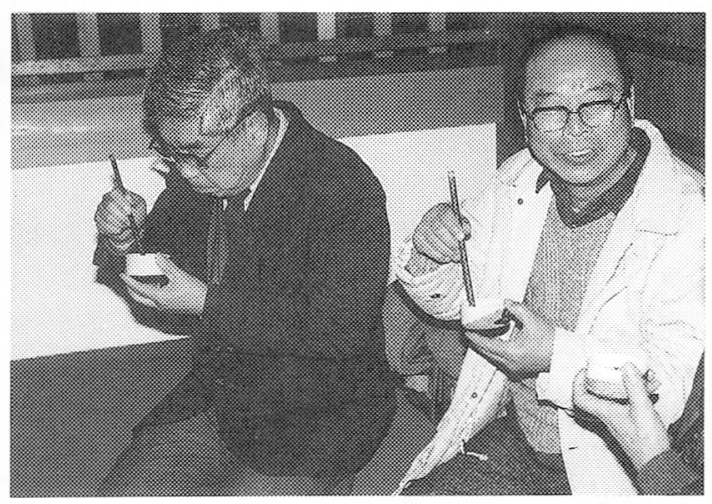

写真 9 参詣者は青竹の一本箬で振るまわれる小豆粥を食べる （小許曽神社）

翌 1 月 15 日, 早朝 7 時から「奉賛（ぶさん）神事」が 行われる. 太平洋戦争前までは, 氏子全員が参加してジ ネギ（地祢宜）と宮当番の家で行われていたが，現在は， 地域の代表者 9 人だけが参加して, 小許曾神社の社務所 を会場にして実施される.この神事は, 氏子の結束を固 めるために行われる会食で，三重県伊賀地方にも「宗旨 (しゅうし) 祭り」あるいは「そらし」といっている類 似の行事が存在し，氏神の例祭をこのようにい5ことも ある31. 小許曽神社の係には，氏子総代と宮当番がある。 氏子総代は選挙により 5 人選ぶが, 宮当番は 1 年ごとに 15人ずつ代わっている。それは戸主が努めることになっ て扣り，家の並びに従い順番が決まっている．13年か14 年に一度の周期で回ってくるといわれ，地袮宜と呼ばれ る代表者が合議の上で決められる。これは民間から出る 
一年神主である。「当（頭・帱とも書く）屋制」の一形 式であるら，神社に関する奉仕は宮当番が行う.太平洋 戦争前までは, ミヤタ（宮田）と呼ばれる神社所有の土 地があり，これを耕作するのは重要な任務であった。神 社の薪集め, 神社へ供兄てあった鏡餅を細かく切って各 戸へ配る仕事, 幟立て, 提灯屋台飾りなどが主な仕事で あるが，小許曽神社の祭事は年間 21 回にも及び，宮当番 は一年中大変な奉仕活動を強いられる8).

奉賛行事は進行係である地祢宜が定められた献立を口 上で紹介しながら進められる. 最初に地称宜は扇を前に 置いて一礼し「あけまして扔めでとらございます」と挨 拶する、「まず御神酒を出させていただきます」と口上 すると,つづいて給仕係が各人の妿器に神酒をついでま わる. 次に「それでは御膳を出させていただきます」と いらロ上につづいて給仕倸は順番にひとりずつ角膳を配 る. 膳には手前左に一の汁の椀（中には何も入っていな い), 手前右に飯椀, 右手奥に二の汁の椀（汁の実であ るささがきごぼう，ゆでた百䲘，角切りの焼き豆腐が入 れてある), 左手奥になますの小四（大根と人参で作っ たなますを縦二列に細長く盛り, その上にたつくりがの せてある), 中央に酒用の茶碗, 手前飞箸之柳で作った 楊子がのせてある. 以下口上につづいて一の汁（大根の $1 \mathrm{~cm}$ の角切りを入れた赤味噌汁), 御飯 (給仕係は給仕 盆に飯椀をらけとり飯櫃の御飯をよそう), 打酒 (茶碗 を盆にとり湯桶から注ぐ), 御飯, 二の汁 (給仕係が椀 飞熱い澄まし汁を注ぐ）, 抢酒, 御飯, 漬け物 (2 人分 が小皿に盛られて配られる), 打茶（湯吞み茶碗に入れ て各人に配る), 焼き物（小皿に半紙を敷き，その上に 生の塩鰯をのせて配る）の順に給仕される。「これで終 了させていただきます」の言葉を地袮宜がいらと奉賛の 行事は終了する. この会食形式は酒（御神酒は別）の前 に御飯を供すといら古い日本の食事様式が残っていると 考觉られる。

「奉賛神事」の後, 「当渡し神事」が神社の拝殿で行 われる.これは宮当番の新旧交代の儀式である.

\section{4. おわりに}

前報9）も含めて三重県における坫占いをまとめると，

1）弹占いは, 三重県内では四日市市小古曽町から松阪 市小阿坂町までの鈴鹿川流域以南の地域に分布してい た.これは伊勢平野の米作地帯の中心地である(図 1).

2) 占う対象は, 稲作の早稲・中稲・晚稲の 3 種類が多 く, 稲作での作付品種の変化応じて占いの対象も変 化した例もある.三重県の例では最も多かったのは菅

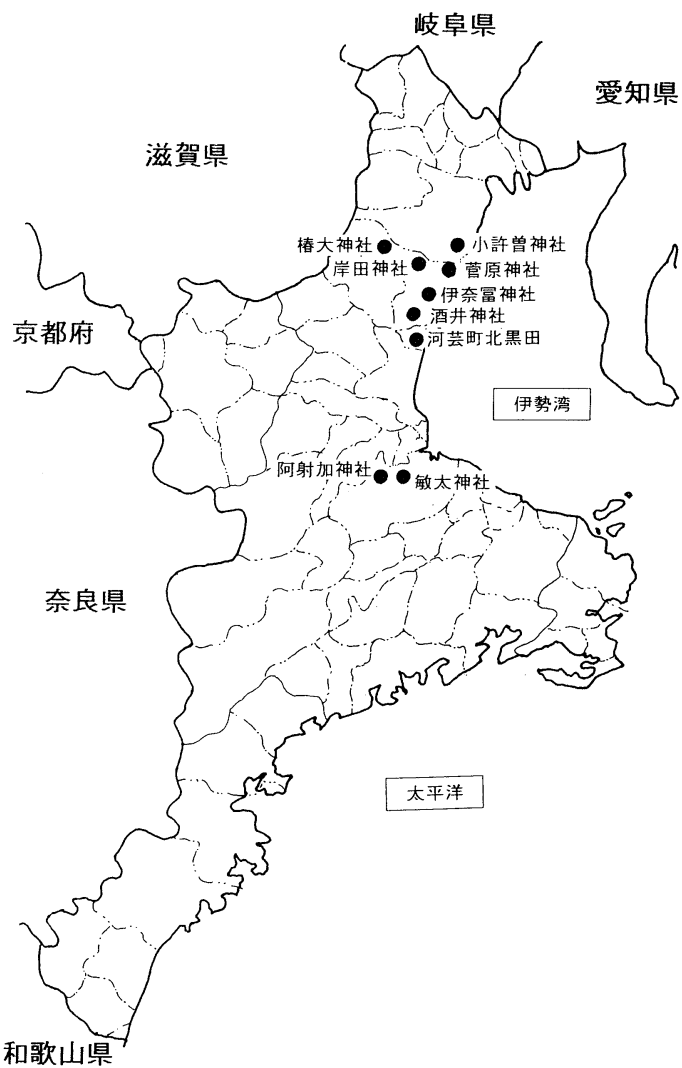

図 1 三重県における粥占いの分布

原神社の 12 種であった．文献1)によれば占ら対象は 36 種，42種あるいは53種の例2) もあることから，三重県 飞残っている粥占いの対象はかなり少ない。

3）粥占いは，打扣むね神社で催されるものが多いが， 神事とは切り離して実施される例（菅原神社・岸田神 社 ${ }^{11)}$ ·河芸町の仏式）もあることから，小正月の民 俗行事としてムラや各家で行われていたものが，後に 神事の中に取り込まれた可能性が高いと判断される.

4）1月15日中心の行事が太陽暦への移行に伴って，2 月15日に実施される場合もでてきたものと考兄られる が, その他の実施日もみられたので, 今後検討したい，

5）粥占いの原型は 1 月14日の深夜の行事ではなかった かと考光られるが，夕刻に実施される例が多くなった。 古くは日没から一日がはじまるとされていたからであ $3^{13)}$.

6）いくつかの地域では，小豆を加光た张で占いが行わ れている. 小正月には小豆粥やぜんざいを食べて無病 息災を願う風習が残っていることとの関連が考兄られ る. 
7）農業の方法や作付け作物も変化し，占いの実効性は なくなっているものの，地域によっては多くの氏子参 加の民俗行事として伝承に務めているものもある.

\section{参考文献}

1) 倉林正次編 : 日本のまつり・年中行事事典, 桜楓社, 東 京, p. 118, p. 290 (1983)

2）野本寛一：稲作民俗文化論，雄山閣，東京，pp. 491-492 (1993)

3）三重県神職会編 : 三重県下の特殊神事（1938）

4）「日本の食生活全集 三重」編集委員会編：聞き書き三重 の食事, 農山漁村文化協会, 東京, pp. 85-86（1987）

5）伊勢志摩編集室編 : 三重の祭, p.28（1994）
6）松浦良代 : 祭りごよみ松阪, 三重県郷土資料刊行会, pp 14-16 (1983)

7）清水桂一編：たべもの語源辞典, 東京堂出版, 東京, p. 5 (1983)

8）四日市市史誌編纂室編：四日市市史 第五巻 資料編民 俗, 四日市市, pp. 526-532 (1995)

9）久保さつき·西村亜希子・水谷令子：三重県に打ける「砩 占い」神事, 鈴鹿短期大学紀要, 第16巻, pp. 65-70（1996）

10）大塚民俗学会編：日本民俗辞典, 弘文堂, 東京, p. 171 (1972)

11）鈴鹿市教育委員会編：鈴鹿市史 第三巻, 鈴鹿市, pp. 653-654 (1989)

12）田中義広編：日本の祭り事典, 淡交社, 京都, p. 43 (1991)

13）須藤功：葬式一あの世への民俗, 青弓社, 東京, p. 112 (1996) 